\title{
BIOLOGY OF NYMPHS OF Rhodnius robustus LARROUSSE, 1927 (HEMIPTERA, REDUVIIDAE), FED ON PIGEON OR ON SWISS MOUSE BLOOD IN LABORATORY CONDITIONS
}

\author{
BRAGA, M. V., ${ }^{1}$ PRATA, K. C. ${ }^{1}$ and BRAZIL, R. P. ${ }^{2}$ \\ ${ }^{1}$ Laboratório de Biologia e Controle de Insetos Vetores, Departamento de Biologia, Instituto Oswaldo Cruz, \\ FIOCRUZ, Av. Brasil, 4365, Manguinhos, CEP 21045-900, Rio de Janeiro, RJ, Brazil \\ ${ }^{2}$ Laboratório de Leishmanioses, Centro de Pesquisas René Rachou, FIOCRUZ, Belo Horizonte, MG, Brazil \\ Correspondence to: Marina Vianna Braga, Laboratório de Biologia e Controle de Insetos Vetores, Departamento de \\ Biologia, Instituto Oswaldo Cruz, FIOCRUZ, Av. Brasil, 4365, Manguinhos, CEP 21045-900, Rio de Janeiro, RJ, \\ Brazil, e-mail: mvbraga@gene.dbbm.fiocruz.br
}

Received September 22, 1997 - Accepted July 05, 1998 - Distributed February 23, 1999

(With 1 figure)

\begin{abstract}
The duration of the life cycle of Rhodnius robustus Larrousse, 1927 as well as the mortality rate of each nymphal instar were studied comparing groups fed on pigeon or on mouse blood weekly or fortnightly. This species showed a better development and lower mortality rate when fed on swiss mouse. The intervals between feedings apparently did not have influence on the shortening of the cycle. We suggest that laboratory colonies and experiments with $R$. robustus are better maintained when these triatomines are fed on swiss mouse.
\end{abstract}

Key words: Rhodnius robustus, biology, life cycle, feeding preference.

\section{RESUMO}

\section{Biologia de ninfas de Rhodnius robustus Larrousse, 1927 (Hemiptera, Reduviidae), alimentadas em pombo ou em camundongo albino sob condições de laboratório}

A duração do ciclo de vida de Rhodnius robustus Larrousse, 1927, bem como a taxa de mortalidade de cada estádio ninfal foram estudadas comparando-se grupos alimentados em sangue de pombo ou de camundongo albino semanal ou quinzenalmente. Esta espécie apresentou um melhor desenvolvimento e menor taxa de mortalidade quando alimentada em sangue de camundongo albino. Os intervalos entre as alimentações aparentemente não tiveram influência sobre a redução do ciclo. Sugerimos que colônias de laboratório e experimentos com $R$. robustus são melhor mantidos quando estes triatomíneos são alimentados em camundongo albino.

Palavras-chave: Rhodnius robustus, biologia, ciclo de vida, preferência alimentar.

\section{INTRODUCTION}

Rhodnius robustus Larrousse, 1927, is a sylvatic triatomine found in Brazil in the States of Amazonas and Pará. It is found also in Bolivia, Colombia, Ecuador, French Guiana, Peru and Venezuela (Lent \& Wygodzinsky, 1979). Carcavallo et al. (1975) and Tonn et al. (1976) found $R$. robustus naturally infected in Venezuela by Trypanosoma cruzi Chagas, 1909, causative agent of Chagas' disease, and with mixed infections of T. cruzi and Trypanosoma rangeli Tejera, 1920.

Until now the life cycle of this triatomine has not been studied with emphasis on the kind of blood or the intervals between feedings that would be more adequate for its maintenance in the laboratory.

This study aimed to verify the duration of the life cycle of this species fed on pigeon or on 
mouse blood weekly or fortnightly and the mortality rate of each nymphal instar.

\section{MATERIAL AND METHODS}

The tests were iniciated with $1^{\text {st }}$ instar nymphs from the first generation of a colony maintained in our laboratory. This colony originated from nymphs captured in the State of Rondônia, Brazil, by Dr. Sérgio Luz, from the Departamento de Entomologia, Instituto Oswaldo Cruz, Fundação Oswaldo Cruz, Rio de Janeiro, Brazil.

As soon as the hatchings occurred, the first instar nymphs were separated into four groups: a) fed weekly on swiss mouse $(\mathrm{n}=39)$; b) fed fortnightly on swiss mouse $(\mathrm{n}=34)$; c) fed weekly on pigeon $(\mathrm{n}=50)$; d) fed fortnightly on pigeon ( $\mathrm{n}$ $=50$ ). The insects were fed until repletion.

Each instar was put in separate glass containers wrapped by a black cardboard and closed with nylon mesh bound by an elastic band. A disk of filter-paper was placed on the bottom of the containers in order to absorb the insects' excretion. A rectangular piece of filter-paper was folded and placed vertically inside the container so that the insects could use it as a supporting surface. They were kept at room temperature $\left(20^{\circ} \mathrm{C}\right.$ to $31{ }^{\circ} \mathrm{C} ; 81.3 \% \pm 10 \%$ relative humidity). The number of ecdysis and the mortality of the nymphs during the five instars were recorded. The results were statistically analyzed through the Kruskal-Wallis one-way test and the Qui-square test (Siegel, 1956).

\section{RESULTS}

All instars from both groups fed on swiss mouse had shorter duration than the ones fed on pigeon, with exception of the 1 st instar for the group fed weekly on swiss mouse. The instars had a mean duration that ranged from, approximately, 20 to 30 days when the nymphs were fed on swiss mouse, while when they were fed on pigeon, the instars tended to increase the duration varying from, approximately, 30 to 50 days (Fig. 1). All results were statistically significant. The group fed fortnightly on swiss mouse had better results than the one fed weekly (Table 1).

The mortality was higher for both groups fed on pigeon, with exception of the $2^{\text {nd }}$ and $5^{\text {th }}$ instars, during which it was also high for both groups fed on mouse. The total mortality rates at the end of the complete cycle were very high for the groups fed weekly and fortnightly on pigeon. The lowest total mortality occurred in the group fed weekly on swiss mouse. The results were statistically significant for the $1^{\text {st }}, 3^{\text {rd }}$, and $5^{\text {th }}$ instars and for the complete cycle (Table 2).

\section{DISCUSSION}

$R$. robustus is considered a very important species due to its close relation to Rhodnius prolixus Stal, 1859 the most important vector of Chagas disease in Brazil with which it shares most morphological and chromatic characters (Lent \& Wygodzinsky, 1979).

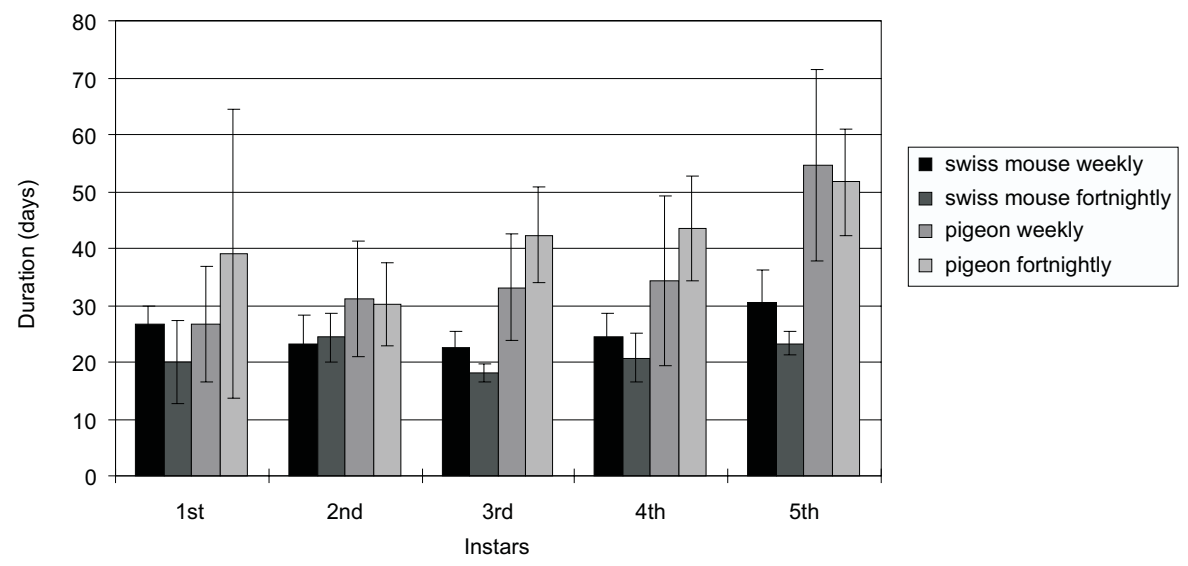

Fig. 1 - Means and standard deviations of the duration of each instar of Rhodnius robustus fed on swiss mouse or on pigeon. 
TABLE 1

Results of the Kruskal-Wallis' statistical test comparing the groups fed weekly or fortnightly on swiss mouse or on pigeon by instar. SMW = fed weekly on swiss mouse; SMF = fed fortnightly on swiss mouse; PGW = fed weekly on pigeon; PGF = fed fortnightly on pigeon.

\begin{tabular}{|c|c|c|c|}
\hline Instars & $\begin{array}{l}\text { Kruskal- } \\
\text { Wallis }\end{array}$ & $\begin{array}{c}\text { Significance } \\
\text { level }\end{array}$ & Statiscal order of the groups \\
\hline 1st & 27.2 & $<0.05$ & $\mathrm{PGF}>\mathrm{PGW}>\mathrm{SMW}>\mathrm{SMF}$ \\
\hline 2nd & 37.8 & $<0.05$ & $\mathrm{PGW}>\mathrm{PGF}>\mathrm{SMW}>\mathrm{SMF}$ \\
\hline $3^{\text {rd }}$ & 86.2 & $<0.05$ & $\mathrm{PGF}>\mathrm{PGW}>\mathrm{SMW}>\mathrm{SWF}$ \\
\hline 4th & 47.7 & $<0.05$ & $\mathrm{PGF}>\mathrm{PGW}>\mathrm{SMW}>\mathrm{SMF}$ \\
\hline 5th & 39.5 & $<0.05$ & $\mathrm{PGF}>\mathrm{PGW}>\mathrm{SMW}>\mathrm{SMF}$ \\
\hline
\end{tabular}

According to Perlowagora-Szumlewicz (1975), R. prolixus presents a development in the laboratory that is much lower than the results that we obtained for the first, second and third instars and close to the ones we obtained only for the fourth and fifth instars fed on pigeon. The mortality rates of $R$. prolixus are lower than those we obtained for all groups tested.

The insects tested by Perlowagora-Szumlewicz were from the first laboratory generation after they were brought from the field and the author states that the parameters observed changed considerably after the insects were reared for four years in the laboratory.

Jurberg et al. (1970) studied the life cycle of $R$. robustus. The food source and the intervals between feedings were not quoted. The durations that we obtained from the $1^{\text {st }}$ to the $3^{\text {rd }}$ instars for all groups were very close to the ones observed by those authors, however, our results for the $4^{\text {th }}$ and $5^{\text {th }}$ instars were much lower. The mortality rate that we observed for the complete cycle of the groups fed on swiss mouse were lower than the ones that they obtained.

Tonn et al. (1976) fed $R$. robustus on hen at intervals of ten to 14 days and Jurberg \& Rangel (1980) fed this species daily on pigeon. The results of the $4^{\text {th }}$ and $5^{\text {th }}$ instars of both groups fed on swiss mouse were lower than the ones that these authors obtained. However, the mortality rates that we observed were higher.

Corrêa (1962) studied the life cycle of Triatoma infestans Klug, 1834 comparing their development when fed on hen, opossum or dog. Our results for the $1^{\text {st }}, 2^{\text {nd }}$ and $3^{\text {rd }}$ instars of the four groups were higher than the ones that this author obtained.

Diotaiuti \& Dias (1987) made a comparison between the life cycles of Rhodnius neglectus Lent, 1954 fed fortnightly on pigeon or swiss mouse (anaesthetized with Nembutal). The durations of the $1^{\text {st }}, 2^{\text {nd }}$ and $3^{\text {rd }}$ instars of their group fed on pigeon were shorter and the mortalities, generally, lower than the ones we observed. The durations that we obtained for the groups fed on swiss mouse were lower than theirs for all instars and the mortality rates that we obtained were higher for the $2^{\text {nd }}, 3^{\text {rd }}$ and $5^{\text {th }}$ instars.

In our study, when feeding on swiss mouse blood, $R$. robustus showed a better development and lower mortality rate, but the interval between the meals apparently did not influence the shortening of the cycle.

Our results suggest that laboratory colonies and experiments with $R$. robustus are better maintained when these triatomines are fed on swiss mouse. According to the TDR News (O.M.S., 1997) the Task Force on Operational Research on Chagas' Disease is focusing its activities on the population dynamics of non-domiciliated triatomine vectors of Chagas' disease present in the northern part of South America and in Central America. Still according to this report, research is needed on various aspects of triatomines' epidemiology for a better understanding of its biosystematics and control.

Acknowledgments - To Dr. Sérgio Luz, from the Departamento de Entomologia, IOC, FIOCRUZ, Rio de Janeiro, Brazil, who gave us the insects that originated our colony. 
TABLE 2

Mortality rates of each instars of Rhodnius robustus of the groups fed weekly or fortnightly on swiss mouse and on pigeon; $\mathbf{n}=$ number of nymphs that started each instar; $\uparrow=$ number of nymphs that died in each instar; $\chi^{2}=$ Chi-square test; $p=$ significance level; NS = non-significant.

\begin{tabular}{|c|c|c|c|c|c|c|c|c|c|c|c|c|c|c|}
\hline \multirow{3}{*}{ Instars } & \multicolumn{6}{|c|}{ Fed on swiss mouse } & \multicolumn{6}{|c|}{ Fed on pigeon } & \multirow[b]{3}{*}{$\chi^{2}$} & \multirow[b]{3}{*}{$\mathbf{p}$} \\
\hline & \multicolumn{3}{|c|}{ Weekly } & \multicolumn{3}{|c|}{ Fortnightly } & \multicolumn{3}{|c|}{ Weekly } & \multicolumn{3}{|c|}{ Fortnightly } & & \\
\hline & $\mathbf{n}$ & $\dagger$ & $\%$ & $\mathbf{n}$ & $\dagger$ & $\%$ & $\mathbf{n}$ & $\dagger$ & $\%$ & $\mathbf{n}$ & $\dagger$ & $\%$ & & \\
\hline $1^{\text {st }}$ & 39 & 00 & 0.0 & 34 & 02 & 2.9 & 50 & 08 & 16.0 & 50 & 09 & 18.0 & 9.5 & $<0.05$ \\
\hline $2^{\text {nd }}$ & 39 & 09 & 23.1 & 32 & 12 & 37.5 & 42 & 06 & 14.3 & 41 & 08 & 19.0 & 5.8 & NS \\
\hline $3^{\text {rd }}$ & 30 & 00 & 0.0 & 20 & 00 & 0.0 & 36 & 01 & 2.7 & 33 & 05 & 15.0 & 9.8 & $<0.05$ \\
\hline $4^{\text {th }}$ & 30 & 01 & 3.3 & 20 & 02 & 10.0 & 35 & 03 & 8.6 & 28 & 04 & 14.2 & 2.2 & NS \\
\hline $5^{\text {th }}$ & 29 & 08 & 27.6 & 18 & 05 & 27.7 & 32 & 22 & 68.8 & 24 & 17 & 70.8 & 18.0 & $<0.05$ \\
\hline $\begin{array}{c}\text { Complete } \\
\text { cycle }\end{array}$ & & 18 & 46.2 & & 21 & 61.8 & & 40 & 80.0 & & 43 & 86.0 & 18.8 & $<0.05$ \\
\hline
\end{tabular}

\section{REFERENCES}

CARCAVALLO, R. U., MARTINEZ SILVA, R., OTERO, M. A. \& TONN, R. J., 1975, Infección natural de Rhodnius robustus Larrouse y Rhodnius pictipes Stal por T. cruzi y $T$. rangeli en Venezuela. Bol. Dir. Malariol. San. Amb. 15: 117-120.

CORRÊA, F. M. A., 1962, Estudo comparativo do ciclo evolutivo do Triatoma infestans alimentado em diferentes animais (Hemiptera, Reduviidae). P Av Dep Zool S Paulo, 15: $177-200$.

DIOTAIUTI, L. \& DIAS, J. C. P., 1987, Estudo comparativo do ciclo evolutivo de Rhodnius neglectus alimentados em pombos ou camundongos. Rev. Soc. Brasil. Med. Trop., 20: $95-100$.

JURBERG, J. \& RANGEL, E. F., 1980, Observações sobre Rhodnius robustus Larrousse, 1927 e Rhodnius pallescens Barber, 1932 (Hemiptera, Reduviidae, Triatominae). Rev. Brasil. Biol., 40: 569-577.

JURBERG, J., REIS, V. R. G. \& LENT, H., 1970, Observações sobre o ciclo evolutivo, em laboratório, do Rhodnius robustus Larrousse, 1927 (Hemiptera, Reduviidae, Triatominae). Rev. Brasil. Biol., 30: 477-481.
LENT, H. \& WYGODZINSKY, P., 1979, Revision of the Triatominae (Hemiptera, Reduviidae), and their significance as vectors of Chagas disease. Bull. Amer. Mus. Nat. Hist., 163: 125-520.

O.M.S., 1997, TDR News. Non-domiciliated triatomines. UNDP, World Bank, 54: 10.

PERLOWAGORA-SZUMLEWICZ, A., 1975, Laboratory colonies of Triatominae, biology and population dynamics. In: American Trypanosomiasis Research. PAHO Scientific Publication, 318: 63-82.

SIEGEL, S., 1956, Nonparametric Statistics for the Behavioral Sciences. New York, McGraw-Hill eds., 350p.

TONN, R. J., CARCAVALLO, R. U. \& ORTEGA, R., 1976, Notas sobre la biología, ecología y distribución geográfica de Rhodnius robustus Larrousse, 1927 (Hemiptera, Reduviidae). Bol. Dir. Malariol. San. Amb., 16: 158-162. 